\title{
Quality of Water Adjusted Sources and Storage in the Households of the Sanitized Villages in Area of National Program of Sanitized Schools and Villages at Tshopo Province in Republic Democratic of Congo
}

\author{
Eugène Longembe Basandja ${ }^{1}$, Gaston Kimbwani Mabela² ${ }^{2}$ Zoé-Arthur Kazadi Mulumba ${ }^{3,4}$, \\ Jean Panda Lukongo Kitronza1,5, Joris Losimba Likwela ${ }^{*}$
}

\footnotetext{
${ }^{1}$ Department of Public Health, Faculty of Medicine, University of Kisangani, Kisangani, Democratic Republic of Congo

${ }^{2}$ Department of Psychology, Faculty of Psychology and education Sciences, University of Kisangani, Kisangani,

Democratic Republic of Congo

${ }^{3}$ Department of Biotechnological Sciences, Faculty of Sciences, University of Kisangani, Kisangani, Democratic Republic of Congo ${ }^{4}$ Station control room of Biodiversity (CSB), University of Kisangani, Kisangani, Democratic Republic of Congo

${ }^{5}$ Public Health, Faculty of Medicine, University of Liege, Belgium

Email: *jorislikwela@gmail.com
}

How to cite this paper: Basandja, E.L., Mabela, G.K., Mulumba, Z.-A.K., Kitronza, J.P.L. and Likwela, J.L. (2021) Quality of Water Adjusted Sources and Storage in the Households of the Sanitized Villages in Area of National Program of Sanitized Schools and Villages at Tshopo Province in Republic Democratic of Congo. Journal of Biosciences and Medicines, 9, 43-54. https://doi.org/10.4236/jbm.2021.96004

Received: March 16, 2021

Accepted: June 4, 2021

Published: June 7, 2021

Copyright $(2021$ by author(s) and Scientific Research Publishing Inc. This work is licensed under the Creative Commons Attribution International License (CC BY 4.0).

http://creativecommons.org/licenses/by/4.0/ (c) (i) Open Access

\begin{abstract}
Introduction: The present research paper aims at assessing the bacteriological water quality in households and at provisioning points, and so factors of water deterioration. Method: a transverse study has been conducted during the period starting from 11 up to 28 October 2018 within 6 Health Zones (HZ) in Tshopo Province integrated in National Program of Schools and Sanitized Villages (NPSSV). Water samples have been collected within 300 reserves of households and 30 water provisioning and analysed points in order to find out water contamination factors. The frequencies and raw OR have been estimated at $(\mathrm{p}<0.05)$ valued significative. Results: fecal coliforms $(80 \%$ CI95: $75 \%$ - 85\%) and total (97\% CI95: 95\% - 99\%) were significantly present in water reserves and the presence of Escherichia coli were at about $27 \%$ (IC95 22\% - 32\%). These proportions were correspondingly at 63\%, 90\% and $10 \%$ at water provisioning. The fecal coliforms were the highest in water reserves of sanitized villages $(\mathrm{p}<0.05)$ and Escherichia coli were at about three times higher in traditional sources ( $17 \%$ vs $6 \%)$. The duration of water conservation was around 48 hours and more $(\mathrm{OR}=4.41$; IC95: $1.92-10.11)$, water classification of sanitized risk "intermedium" and the recipients of conservation with bottleneck were associated with the presence of E.coli in water
\end{abstract}


$(\mathrm{p}<0.05)$. Conclusion: water from provisioning sources and household reserves are severely polluted and water quality is not good at consumption point and at provisioning point. The reinforcement of safety measures at water points, reduction of conservation length and hygienic water cleaning of storage water recipients are necessary to assure quality of water.

\section{Keywords}

Water Quality, Households, Supplied Points, Sanitized Village, Tshopo, Democratic Republic of Congo

\section{Introduction}

Access to salubrious water and the sanitary means for excrement evacuation are versatile needs and even fundamental human rights. However, many people in the world, especially in low-income countries, do not have access to adequate and safe water [1].

Today, approximate one billion people, mostly living in developing countries don't have access to potable and adequate water [2]. In 2012, 1.9 billion of population has consumed either a non-sanitized source or a sanitized source of water presenting fecal contamination [3].

In the same year (2012), it was estimated that 502,000 deaths due to diarrhoea were caused by a lack of drinkable water [4].

A systematic study has been conducted in 2005 revealed that diarrhoeal episodes are reduced of $25 \%$ if water supply is improved and of $39 \%$ by the treatment and proper conservation of water at home [5].

The essential role that relative interventions in water quality at the point of using (household) should play is to reduce diarrheal episodes confirmed in one review realized in 2006, reporting a reduction of diarrhoeal disease morbidity, almost half on average with some studies reaching a reduction of $70 \%$ or more [6].

Several studies have identified various associated factors with children's diarrhea and contamination of drinking water in households.

In Mauritania, food poisoning (62.5\%), poor drinking water quality (29.1\%), poor household hygiene, prolonged water conservation of 48 hours on average (65.2\%) have been identified and insufficient water chlorination (42.6\%) [7].

In Abidjan, the place of preservation, the type of water storage containers and certain risky due to bad behaviours (child eats without washing his hands), were identified as factors associated factors with diarrhea [8].

Water storage is an important step in the contamination of water at the point of use. Several studies have identified factors in deteriorating water quality at home.

In Cambodia Unhygienic water storage and handling practices were found to be strongly correlated with microbial contamination of water samples [9]. In 
Canada and Peru, households that had access to water by plunging hands or a cup had significantly high e-levels E. coli compared to households that extracted water through the toppling pouring; also, households with covered containers less than those with open containers [9] [10] [11].

In Cameroon, the nature of the container, the duration of conservation, the characterization of the water intake (extracting technique) and the transport conditions (container and distance travelled) were strongly correlated with water contamination [12]. After three days of water conservation, more than $80 \%$ of the water samples analysed was of bad quality. Households which had running water at home could not keep drinking water for a long period of time and were less exposed to health risks than others [12].

In the DRC, a study has been conducted in South Kivu, concluded that water quality was not generally as well as at sources [13].

With the DRC's National Program of Sanitized Schools and Village (NPSSV), there is currently insufficient evidence to determine whether source-based improvements such as protected wells, collective taps or chlorination/filtering of community sources which systematically reduce diarrhea [6].

This study is being conducted in order to assess the bacteriological quality of water in managed points and water supplies, as well as the factors of deterioration in quality observed at the post-certification household level.

\section{Method}

An analytic cross study has been conducted in Health Zones (HZ) in Tshopo Province integrated in National Program of Sanitized Schools and villages (NPSSV) within period covering from 11 to 28 October 2018 by sampling cascading technique in three levels. At the first level (6) Health Zones have been randomly selected among (10) Health Zones integrated into process of certification of villages under NPSSV program since 2014. At the second level, in each selected Health Zone, three (3) certified villages and two (2) non-integrated villages into the certification process are randomly selected from exhaustive list of villages of these two categories. At the third level, 22 households were selected in each village by systematic sampling techniques after the survey housing units.

The sample size of households to be investigated was calculated by using formula below:

$$
n=Z^{2} * p q / d^{2} .
$$

Considering that the coverage of population in terms of water of managed springs is one of the important indicators of the NPSSV. This coverage being estimated at $47 \%$ in the DRC (MICS-DRC, 2010), with the $\mathrm{Z}$ coefficient $=1.96$, the error is located at 0.04 and an anticipated non-response rate of $10 \%$, the sample size calculated for interview was 658 households.

These households were distributed in $6 \mathrm{HZ}$ due to 110 per $\mathrm{HZ}$ and through 18 certified villages (396 households) and 12 villages not integrated in the certification process (264 households). 
These households have been interviewed to assess the knowledge and practices of households in terms of security management of water. Due to insufficient logistic supports, the collection of water samplings for bacterial quality analysis has been realised within 300 households randomly selected among the 658 households in terms of 10/22 households interviewed in each village among 30 ones.

However, the qualified households have been are those which have less than one child from 0 to 59 Months.

In each village, one water point has been randomly sampled in order to collect the water samples and bacterial analysis among water points exiting in the village. Three samples of water have been collected in each 18 certified water points, 12 non certified water points and of 300 reserves of water in households (172 households of sanitized villages and 120 households of villages non-integrated in certification process).

The bacteriological analysis has been carried out with the Wagtech ${ }^{\mathrm{Tm}}$ Potatech $\odot$ (Figure 1) in order to check and count the witness germs of fecal contamination, especially the fecal coliforms, total coliforms and Escherichia coli.

It has been realized as follow:

- Sampling an infertile sample of water;

- Infertile culture of membrane;

- Incubation at $44^{\circ} \mathrm{C}$ during 18 hours;

- Identification to the naked eye of the present bacteria forming the colonies;

- Enumeration of expressed bacteria in unity numbers forming colonies for $11 \mathrm{ml}$ of oozed water.

The sanitary inspection has been realized by using the technique of observation, especially around water provisioning in order to assess the following security parameters: the presence or absence of the fence, the existence or inexistence of protection perimeter (water divergence canal of stream), easy access of children and goats, the presence of animals' excrements, puddles of water around, dirty aspects in the Zone, the presence of latrines and/or graveyard upheaval.

Data have been recorded and analysed in SPSS 20 software program and the exported tables on Excel. The statistics focused on frequency measurement and gross OR at the significance threshold of 0.05 .

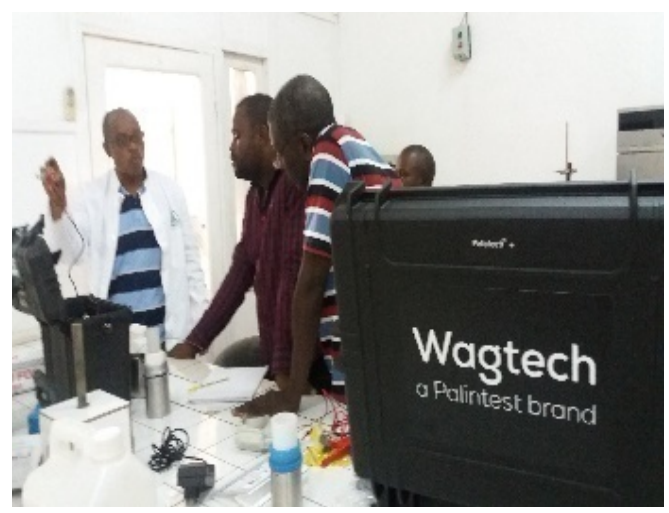

Figure 1. Mobile lab WagtechTM Potatech@ used for water quality analysis. 


\section{Limits of the Study}

The present research paper did not take into account to the physic-chemical parameter analysis because it was influenced most of cases by hydro geologic configuration of each area. We focused on influenceable parameters by environmental practices and conditions of work users of water provisioning. Three major indicators have been analyzed in this research paper: the fecal coliforms and total Escherichia coli. The analysis of associated factors to water contamination has limited with the presence of Escherichia coli in water reserves.

\section{Results}

This research paper found the significant presence of fecal coliforms in water reserves. Therefore 4 households among 5 and total coliforms almost in household water supplies. Fecal coliforms were significantly elevated in the water reserves of sanitized villages $(\mathrm{p}<0.05)$. At waterpoints, these proportions are comparable for total coliforms but low for fecal coliforms and $E$ coli. The proportion of waterpoints with $E$. coli is about three times higher in traditional sources than in managed sources, but the difference is not significant $(p>0.05)$ (Table 1).

In this study, about half of the water reserve of households and provisioning water points classified "intermedium risk", significantly different from other categories of risk for water of reserve $(\mathrm{p}<0.05)$ and non-significative for provisioning of water points $(\mathrm{p}>0.05)$ (Table 2$)$.

The study shows that only the presence of protective perimeters around water supply points is significantly different between the two categories of water points in favor of managed water points $(\mathrm{p}>0.05)$. All other safety parameters are the same although unimproved (traditional) sources are located far from toilets and cemeteries (Table 3).

It has been observed in this table that the length of water conservation more than 24 hours, medium class of risk according to WHO criteria and the recipients of water conservation with bottleneck are significantly associated to the presence of E. coli in reserve of water $(\mathrm{p}<0.05)$ (Table 4).

Table 1. Distribution of reserve water samples in households and sources of supply based on fecal contamination parameters.

\begin{tabular}{|c|c|c|c|c|c|c|c|c|}
\hline \multirow{2}{*}{ Variable } & \multirow{2}{*}{ Parameters } & \multicolumn{2}{|c|}{ Certified Villages $(n=172)$} & \multicolumn{2}{|c|}{ Non-certified Villages $(n=120)$} & \multicolumn{2}{|c|}{ Together $(n=292)$} & \multirow{2}{*}{ p-value } \\
\hline & & Frequency & $\%$ & Frequency & $\%$ & Frequency & $\%$ & \\
\hline \multirow{3}{*}{$\begin{array}{c}\text { Water contamination } \\
\text { parameters in household } \\
\text { water reserve. }\end{array}$} & Fecal coliforms & 145 & 84 & 90 & 75 & 235 & 80 & 0.048 \\
\hline & Total coliforms & 169 & 98 & 115 & 96 & 284 & 97 & 0.212 \\
\hline & Escherichia coli & 43 & 25 & 37 & 31 & 80 & 27 & 0.27 \\
\hline \multirow{2}{*}{ Variable } & \multirow{2}{*}{ Parameters } & \multicolumn{2}{|c|}{ Developed Source $(n=18)$} & \multicolumn{2}{|c|}{ Unmanaged Source $(n=12)$} & \multicolumn{2}{|c|}{ Together $(n=30)$} & 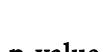 \\
\hline & & Frequency & $\%$ & Frequency & $\%$ & Frequency & $\%$ & P-value \\
\hline \multirow{3}{*}{$\begin{array}{l}\text { Water contamination } \\
\text { settings in sources of } \\
\text { drinking water }\end{array}$} & Fecal coliforms & 12 & 67 & 7 & 58 & 19 & 63 & 0.643 \\
\hline & Total coliforms & 16 & 89 & 11 & 92 & 27 & 90 & 0.804 \\
\hline & Escherichia coli & 1 & 6 & 2 & 17 & 3 & 10 & 0.320 \\
\hline
\end{tabular}


Table 2. Distribution of reserve water samples in households and sources of supply by health risk categories for water according to WHO.

\begin{tabular}{|c|c|c|c|c|c|c|c|c|}
\hline \multicolumn{9}{|c|}{ Water reserve of households } \\
\hline \multirow{2}{*}{ Variable } & \multirow{2}{*}{ Parameters } & \multicolumn{2}{|c|}{ Certified Villages $(n=172)$} & \multicolumn{2}{|c|}{$\begin{array}{c}\text { Non-certified } \\
\text { Villages }(n=120)\end{array}$} & \multicolumn{2}{|c|}{ Together $(n=292)$} & \multirow{2}{*}{ p-value } \\
\hline & & Frequency & $\%$ & Frequency & $\%$ & Frequency & $\%$ & \\
\hline \multirow{4}{*}{$\begin{array}{l}\text { WHO risk } \\
\text { categories }\end{array}$} & Without & 27 & 16 & 30 & 25 & 57 & 20 & \multirow[t]{4}{*}{0.000} \\
\hline & Low & 25 & 15 & 34 & 28 & 59 & 20 & \\
\hline & Intermediate & 105 & 61 & 43 & 36 & 148 & 51 & \\
\hline & High & 15 & 9 & 13 & 11 & 28 & 9 & \\
\hline \multicolumn{9}{|c|}{ Sources of supply } \\
\hline \multirow{6}{*}{ Variable } & \multirow{2}{*}{ Parameters } & \multicolumn{2}{|c|}{ Developed Source $(n=18)$} & \multicolumn{2}{|c|}{$\begin{array}{c}\text { Unmanaged } \\
\text { Source }(n=12)\end{array}$} & \multicolumn{2}{|c|}{ Together $(n=30)$} & $\mathrm{p}$-value \\
\hline & & Frequency & $\%$ & Frequency & $\%$ & Frequency & $\%$ & \\
\hline & Without & 1 & 6 & 2 & 17 & 3 & 10 & 0.699 \\
\hline & Low & 8 & 44 & 4 & 33 & 12 & 40 & \\
\hline & Intermediate & 8 & 44 & 6 & 50 & 14 & 47 & \\
\hline & High & 1 & 6 & 0 & 0 & 1 & 3 & \\
\hline
\end{tabular}

Table 3. Presentation of health inspection results on safety parameters at drinking water supply sites by village category.

\begin{tabular}{|c|c|c|c|c|c|c|c|}
\hline \multirow{2}{*}{ Safety parameters } & \multicolumn{2}{|c|}{ Certified Villages $(n=172)$} & \multicolumn{2}{|c|}{ Non-certified Villages $(n=120)$} & \multicolumn{2}{|c|}{ Together $(n=292)$} & \multirow{2}{*}{ p-value } \\
\hline & Frequency & $\%$ & Frequency & $\%$ & Frequency & $\%$ & \\
\hline Closing presence & 3 & 16.7 & 0 & 0 & 3 & 10.0 & 0.136 \\
\hline Existence of protecting perimeter & 12 & 66.7 & 3 & 25 & 15 & 50.0 & 0.025 \\
\hline Access to small children & 18 & 100 & 12 & 100 & 30 & 100 & \\
\hline Defecation of animals & 7 & 38.9 & 8 & 66.7 & 13 & 43.3 & 0.142 \\
\hline Stagnant water around & 11 & 61.1 & 10 & 83.3 & 21 & 70.0 & 0.193 \\
\hline Unsuitable aspects & 14 & 77.8 & 11 & 91.7 & 25 & 83.3 & 0.317 \\
\hline Latrine upstream & 4 & 22.2 & 0 & 0.0 & 4 & 13.3 & 0.79 \\
\hline Upstream cemetery & 1 & 5.6 & 0 & 0.0 & 1 & 3.3 & 0.406 \\
\hline
\end{tabular}
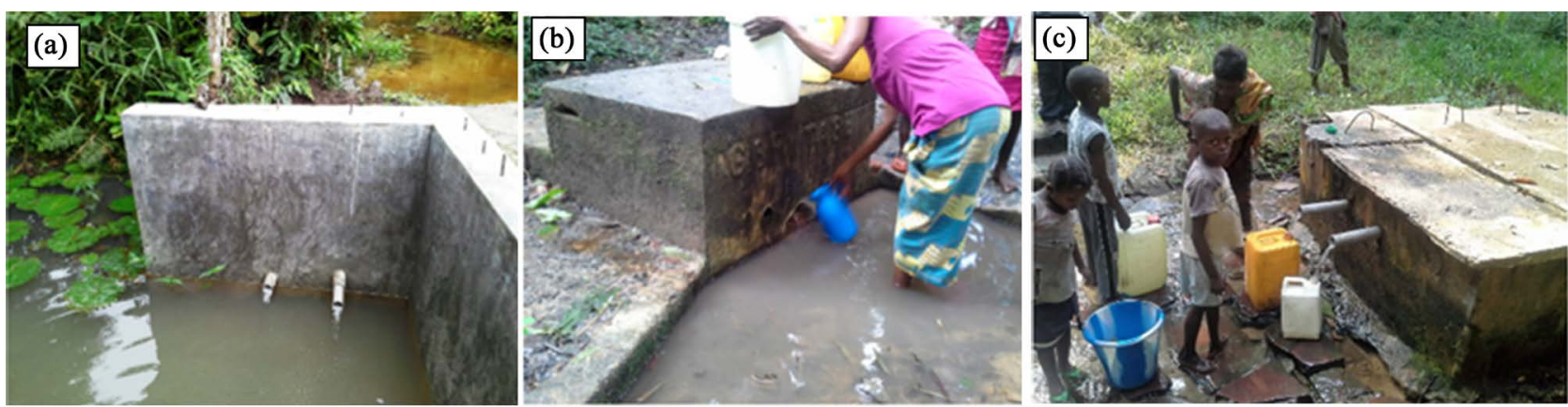

Figure 2. (a) and (b): Work without evacuation chanal creates stagnation; (c) Dilapidated work. 
Table 4. Analysis of associated factors to the presence of Escherichia coli in conservation of water within households.

\begin{tabular}{|c|c|c|c|c|}
\hline \multirow{2}{*}{ Length of storage } & \multicolumn{2}{|c|}{ Escherichia coli } & \multirow{2}{*}{ OR (IC95\%) } & \multirow{2}{*}{ p-value } \\
\hline & Present & Absent & & \\
\hline 24 hours & 7 & 63 & $4.41(1.92-10.11)$ & 0.000 \\
\hline$>24$ hours & 73 & 149 & & \\
\hline \multicolumn{5}{|l|}{ Water treatment } \\
\hline Yes & 17 & 31 & $0.635(0.329-1.225)$ & 0.175 \\
\hline No & 63 & 181 & & \\
\hline \multicolumn{5}{|l|}{ Water access time } \\
\hline$<30$ minutes & 67 & 191 & $177(0.84-3.72)$ & 0.135 \\
\hline$>30$ minutes & 13 & 21 & & \\
\hline \multicolumn{5}{|c|}{ Class of risk according to WHO } \\
\hline Without risk & 5 & 52 & $95.126^{\star *}$ & 0.000 \\
\hline Low risk & 2 & 57 & & \\
\hline Medium risk & 46 & 102 & & \\
\hline High risk & 27 & 1 & & \\
\hline \multicolumn{5}{|c|}{ Types of recipients of conservation } \\
\hline With bottleneck & 67 & 177 & $8.67^{\star *}$ & 0.013 \\
\hline Without bottleneck & 2 & 1 & & \\
\hline With covers & 4 & 1 & & \\
\hline
\end{tabular}

${ }^{*}$ Chi square of Pearson.

\section{Discussion}

Observations in this studyshows that water supply points and especially household water supplies are frequently contaminated. The presence of fecal coliforms, total coliforms and Escherichia coli, with varying degrees of significance, in water from supply points and household reserves is evidence of fecal contamination (Table 1).

About half of the water reserve of households in unsanitized villages is classified as low risk $(\mathrm{p}<0.05)$ and more than half of the water samples of households in sanitized villages are classified as intermediate risk ( $p>0.05)$. Half of the sources of supply are classified as "low risk" and "intermediate risk" without distinction between improved and unimproved sources $(\mathrm{p}>0.05)$ (Table 2).

The household water health risk category found in this study is the same as that of the provincial Tshopo average rated "very high" for about half (48\%) and "very high" for more than half of water sources (60\%) [14].

The contamination of water in provisioning points and the reserves of household is frequently reported in developing countries [9]. In Abidjann, however, the presence of total coliforms in water of reserve within the households was about $81 \%$ (95\% CI: $78 \%$ - 84\%), significantly weaker than in our reserch paper 
(97\% 95\% CI: 95\%-99\%). Therefore, the E. coli presence was significantly higher similar in Abidjan [15] the same in Perou [11], respectively 42\% (95\% CI: 38\% $46 \%$ ) and $43 \%$ (95\% CI: 36\% - 50\%) in accordance with what has been observed in this research paper (27\%; 95\% CI: 22\% - 32\%). Even among the population who consumes water from the River are basically contaminated during a study conducted in Botswana. It has been revealed as follows there was a new water contamination in households, insisting on the needs of simple techiniques and easier to water treatment in household [16]. In South Kivu (Bukavu) in the DRC, the presence of $E$ coli has been observed in $49.5 \%$ in samples collected within household [13], the presence of E. Coli has been observ, which is higher than what is observed in the present research paper (27\% IC95: 22 - 32).

It has been revealed in this research paper that the water quality seems proximately to be not good in households of certified villages (fecal coliforms at $84 \%$; $\mathrm{p}<0.05)$ although the sanitized villages are available in water points of households, the modern toilets, hands washings and a good knowledge of the key practices favourable for the secured water management. However, the proportion of water points with the presence of $E$. coli is about three times higher in the traditional sources than in households' sources (16.7\% vs $5.6 \%)$ even though the observed difference is not significant $(\mathrm{p}>0.05)$.

The observed paradoxal in this resaerch paper for a high risk of contamination in the sanitized villages justified by the proximity of household water with goats divagation without the security measures at the water provisioning points. That is to say lack of fence and lack deviation chanal which creates stagnant water communicating with the rain water, bad construction of infrastucture and/or dilapidated which communicate with water from the stream while raining and aesier access of children as compares to traditional water sources far from dwellings (Figure 2).

Therefore, the observed high contamination of reserve water begins at the supply point and continues at home with risky practices related to storage conditions and less hygienic handling.

Water contamination in program in the areas of intervention was also reported in Benin where the tests of quality found out evidences of fecal contamination (indicated by the presence of $E$. coli) in part of the drinking water at the source and so this problem was exacerbated when water is stored in households [17].

However, the presence of the security perimeters around provisioning water points is significantly different between two categories of water points in favour of certified water points $(\mathrm{p}<0.05)$. All other security perimeters are the same even though non certified sources (traditional) are installed far from the toilets and cemetery yards (Table 3 ). This confirms the similarity of water quality between two types of water.

Many associated factors to the water contamination are described within this research paper. In this paper, however, it has been shown that the duration of 
water conservation more than 24 hours (OR = 4.41; IC95: $1.92-10.1)$, the class of inter medium risk according to the criteria given by WHO ( $\mathrm{p}<0.05)$, and recipients of water conservation with bottleneck $(\mathrm{p}<0.05)$ are significantly associated into the presence of $E$. Coli in water of conservation (p < 0.05) (Table 4).

The same observation has been revealed in Mauritania where the conservation of water during 48 hours average has been associated to contamination of water in households and diarrhea [7].

In Cameroun, it has been found deterioration of water quality during home transport and conservation despite the materials used for the storage [18]. More than $80 \%$ of water samples analyzed were bad quality within three days. The households having running water do not store for a long time their potable water. They are not totally exposed to sanitary risk as compares with others.

The type of recipients of storage has an impact on the risk of water contamination in reserve. In Peru, therefore, it has been found households with covered recipients have presented in a clear manner a higher number of $E$. Coli less than those with opened recipients which generally collect water by prolonging the recipients [11].

The manipulation practices of water at home such as "the extension of recipient" have been reported in my predecessors studies as sources of water contamination [9], the fact of pouring water or one container in order to get recipient of water conservation instead of hands or an object was associated to the diminution of risk of water contamination in conservation [11].

The most used recipients of water conservation have bottleneck (Jerrica) and the collection of water is done by water flowing. These recipients are significantly associated to the presence of Escherichia coli in water of reserve ( $\mathrm{p}<0.05)$. They are quoted in several studies as the most represented in households.

In Katana, South Kivu, (DRC), these recipients represented $96 \%$ of types of used recipients [13], it is the same in rural zone of Senegal [19].

In Mauritania, as found within this research paper, these recipients have been associated at $68.5 \%$ to water contamination during conservation [20]. The high risk of water contamination associated with this type of recipient was on insufficiency of hygienic measures of these recipients. The internal part of bottleneck is sometimes inaccessible to brooch during cleaning.

Therefore, these recipients are majority made of plastic and not accessible to cleanse and they are frequently germs supports. The users should learn rigorous measures of cleaning recipients in order to minimize the risk of water contamination in households related to the type of this recipient.

Lack of water treatment and access time of water are not identified in this research paper as factors of water contamination. Therefore, the improvement of water access is generally analysed as health and life determinant of a child [21] and some authors proposed to analyse water access in terms of available quantity, distance from water point and budget related to water purchase. In our site, the geographical accessibility less than 30 minutes is better (88\%). 


\section{Conclusions}

Water from provisioning sources and the reserves of households are highly polluted. The quality of water is better in consumption point than in provisioning point. This research paper does not put in evidence added value of National Program for Sanitized School and Villages in households' practices and so is water quality in households and at provisioning points.

Lack of sufficient security measures around the water provisioning points and some practices of risk of users play an important role in the chain of drinking water contamination.

The NPSSV has to insist on the reinforcement of the security measures around water provisioning points, sensitize the users to rigorous measures of the recipients cleaning of conservation and reduction of water storage less than 48 hours.

\section{Ethical Considerations}

Free and informed consent was obtained from the households surveyed after explaining the purpose of the study and the methods of taking water samples for analyzes. Data from the household survey were anonymized by the research team, which is required to strictly respect the confidentiality of the personal data obtained. Data collection was subject to the approval of administrative and health authorities.

\section{Acknowledgements}

The data collection was jointly funded by UNICEF, UNIKIS and Biodiversity Monitoring Center (BMC/Unikis) as part of the implementation of the project "Risk management of water contamination in households and supply points in sanitized villages".

\section{Authors' Contributions}

Eugène Basandja conceived the protocol and wrote the manuscript. Professor Zoe-Athur Kazadi performed technical support for bacteriological analysis of water. Professor Gaston Kimbwani realized statistical analysis with SPSS software. Professor John Panda reviewed the manuscript. Professor Joris Losimba had corrected the protocol, validated analysis and enriched the manuscript. All authors have validated the final version of the manuscript.

\section{Conflicts of Interest}

The authors declare no conflicts of interest regarding the publication of this paper.

\section{References}

[1] UNICEF and WHO (2010) Rapid Assessment Drinking Water Quality in the Federal Democratic Republic of Ethiopia, Country Report of Pilot Project Implementa- 
tion in 2004-2005. Geneva.

[2] UNICEF and WHO (2012) Progress on Drinking Water and Sanitation. New York.

[3] Nitasha, K. and Sanjiv, T. (2014) Influences of Natural and Anthropogenic Factors on Surface and Groundwater Quality in Rural and Urban Areas. Frontiers in Life Science, 8, 23-39. https://doi.org/10.1080/21553769.2014.933716

[4] Pr€uss-Ust€un, A., Bartram, J., Clasen, T., Colford Jr., J.M., Cumming, O., Curtis, V., et al. (2014) Burden of Disease from Inadequate Water, Sanitation and Hygiene in Low- and Middle-Income Settings: A Retrospective Analysis of Data from 145 Countries. Tropical Medicine and International Health, 19, 894-905. https://doi.org/10.1111/tmi.12329

[5] Fewtrell, L., Kaufmann, R., Kay, D., Enanoria, W., Haller, L. and Colford, J.M. (2005) Water, Sanitation, and Hygiene Interventions to Reduce Diarrhoea in Less Developed Countries: A Systematic Review and Meta-Analysis. The Lancet Infectious Diseases, 5, 42-52. https://doi.org/10.1016/S1473-3099(04)01253-8

[6] Clasen, T.F., Alexander, K.T., Sinclair, D., Boisson, S., Peletz, R., Howard, H.C., Majorin, F. and Cairncross, S. (2015) Interventions to Improve Water Quality for Preventing Diarrhoea. Cochrane Database of Systematic Reviews, 20, 1-201. https://doi.org/10.1002/14651858.CD004794.pub3

[7] Sy, I., Keita, M., Traoré, D., Koné, B., Bâ, K., Boilil Wedadi, O., Fayomi, B., et al. (2014) Eau, Hygiène, Assainissement et Santé dans les quartiers précaire à Nouakchott (Mauritanie): contribution à l'approche écosanté à Hay Saken. VertigO la revue électronique en science de l'environnement (en ligne), 19, 1-20. https://doi.org/10.4000/vertigo.14999

[8] Koné, B., Doumbia, M., Sy, I., Dongo, K., Agbo-Houenou, Y., Houenou, P.V., et al. (2014) Etude des diarrhées en milieu péri urbain à Abidjan par l'approche écosanté. VertigO la revue électronique en science de l’environnement (en ligne), 19, 1-15. https://doi.org/10.4000/vertigo.14976

[9] Shaheed, A., Orgill, J., Ratana, C., Montgomery, M.A. and Jeuland, M.A. (2014) Water Quality Risks of "Improved" Water Sources: Evidence from Cambodia. Tropical Medicine and International Health, 19, 186-194.

https://doi.org/10.1111/tmi.12229

[10] Carlee, J.W., Sargeant, J.M., Edge, V.E., Ford, J.D., Farahbakhsh, K., et al. (2017) Water Quality and Health in Northern Canada: Stored Drinking Water and Acute Gastrointestinal Illness in Labrador Inuit. Environmental Science and Pollution Research, 25, 32975-32987. https://doi.org/10.1007/s11356-017-9695-9

[11] Heitzinger, K., Rocha, C.A., Quick, R.E., Montano, S.M., Tilley Jr., D.H., Mock, C.N., et al. (2015) But Not Necessarily Safe: An Assessment of Fecal Contamination of Household Drinking Water in Rural Peru. The American Journal of Tropical Medicine and Hygiene, 93, 501-508. https://doi.org/10.4269/ajtmh.14-0802

[12] De Man, H., Leenen, E.J., Van Knapen, F. and De Roda Husman, A.M. (2014) Risk Factors and Monitoring for Water Quality to Determine Best Management Practices for Splash Parks. Journal of Water \& Health, 12, 399-403. https://doi.org/10.2166/wh.2014.127

[13] String, G., Mirindi, P., Sangira, J.M. and Lantagne, D. (2017) A Cross-Sectional Study on Water Access within the Healthy Villages and Schools (VEA) Program in the DRC. 40 th WEDC International Conference, Loughborough, 2017, 24-28.

[14] INS, Enquête par grappes à indicateurs multiples (2018) MICS-Palu RDC.

[15] Sackou, K.J., Oga, S., Claon, S., Bama, M., Mbrah Koua, D., Houénou, Y. and Kouakou, K.L. (2012) Conditions d'accès et de stockage de l'eau: Enquête dans les 
ménages en zone périurbaine à Abidjan en 2010. Santé Publique, 24, 133-142. https://doi.org/10.3917/spub.122.0133

[16] Tubatsi, G., Bonyongo, M.C. and Gondwe, M. (2015) Water Use Practices, Water Quality, and Households' Diarrheal Encounters in Communities along the Boro-Thamalakane-Boteti River System, Northern Botswana. Journal of Health, Population and Nutrition, 33, Article No. 21.

https://doi.org/10.1186/s41043-015-0031-z

[17] IOB/BMZ (2011) The Risk of Vanishing Effects: Impact Evaluation of Drinking Water Supply and Sanitation Programmes in Benin. IOB, La Haye.

[18] Ngnikam, E., Mougoue, B. and Tietche, F. (2007) Eau, Assainissement et impact sur la santé: Etude de cas d'un écosystème urbain à Yaoundé. Actes des JSIRAUF, Hanoi 6-9.

[19] Ndiaye, P., Oumar Ba, I., Dieng, M., Fall, C. and Tal Dia, A. (2010) Qualité de l'eau de consommation des ménages: Analyse et plan d'action en zone rurale sénégalaise. Santé Publique, 22, 193-200. https://doi.org/10.3917/spub.102.0193

[20] Conseil en Développement Economique et Social (2011) Ministère de l'Hydraulique et de l'Assainissemen. Etude sur la qualité microbiologique de l'eau en Mauritanie. Revue Unicef.

[21] Howard, G. and Bartram, J. (2003) Domestic Water Quantity, Service Level and Health. WHO, Geneva, 33. 